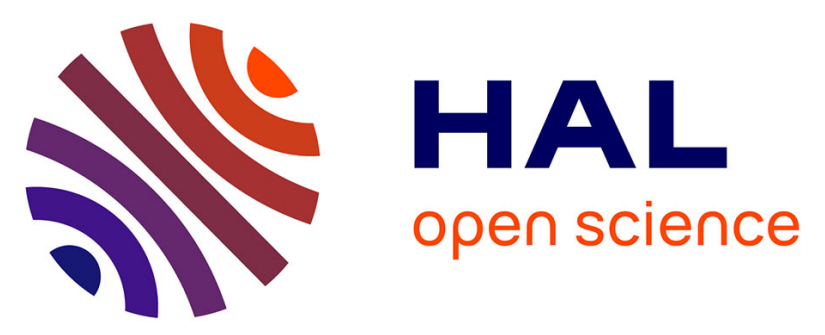

\title{
Discovering unexpected information using a building energy visualization tool
}

Benoit Lange, Nancy Rodriguez, William Puech, Xavier Vasques

\section{To cite this version:}

Benoit Lange, Nancy Rodriguez, William Puech, Xavier Vasques. Discovering unexpected information using a building energy visualization tool. Electronic Imaging, Feb 2013, San Francisco, CA, United States. pp.86500Q, 10.1117/12.2000273 . lirmm-00808118

\section{HAL Id: lirmm-00808118 https://hal-lirmm.ccsd.cnrs.fr/lirmm-00808118}

Submitted on 4 Apr 2013

HAL is a multi-disciplinary open access archive for the deposit and dissemination of scientific research documents, whether they are published or not. The documents may come from teaching and research institutions in France or abroad, or from public or private research centers.
L'archive ouverte pluridisciplinaire HAL, est destinée au dépôt et à la diffusion de documents scientifiques de niveau recherche, publiés ou non, émanant des établissements d'enseignement et de recherche français ou étrangers, des laboratoires publics ou privés. 


\title{
Discovering unexpected information using a building energy visualization tool.
}

\author{
Lange B. ${ }^{a}$, Rodriguez N. ${ }^{a}$, Puech $\mathrm{W} .{ }^{a}$ and Vasques X. ${ }^{b}$ \\ ${ }^{a}$ LIRMM, 141 rue ADA, Montpellier, France; \\ ${ }^{b} \mathrm{IBM}$, Rue de la vieille poste, Montpellier, France
}

\begin{abstract}
In this paper we present a 3D visualization tool developed to gain insight about buildings energy consumption. We will focus on the usage of this software to extract information from a raw dataset, and more especially how unexpected features can be discovered.

In this paper, we will present some related work on data visualization, our visualization tool and finally, two case studies of data analysis using visualization.

This work is developed for the RIDER project (Research for IT Drive efficiencies), composed by several French companies. The goal of this project is to develop a new platform to manage buildings energy. Smart buildings are already managed by BMS (Building Management System) devices. These IT (Information Technology) equipments are used to analyze data from sensors, and then apply some action on the building. These systems are only reactive devices and they are used only to improve immediately buildings environment. Missing features of the actual BMS have been identified and components developed by this project try to solve these gaps. RIDER green box is a more complex BMS, it is composed by a set of predictive components developed to analyze and improve building usage. An example of improvement can be to increase temperature of a meeting room before the arrival of room's users. RIDER is composed by a data mining tool to dig into the large dataset provided by sensors, a model component developed to create building model with a reduced set of parameters, a decisional component develop to improve rules of building management based on user behavior, a visualization component and finally some external components like weather station or calendars.

The visualization engine allows to visualize dataset in an understandable way. We use a particle paradigm for

\footnotetext{
Further author information:

Lange B.: benoit.lange@lirmm.fr

Rodriguez N.: nancy.rodriguez@lirmm.fr

Puech W.: william.puech@lirmm.fr

Vasques X.: xavier.vasques@fr.ibm.com
} 
modeling the space inside a room. This allows to interpolate sensors values and then to visualize. We use particles as presented by Kapferer and Riser. In their work, ${ }^{1}$ particles are static and are use to create a rendering of star in a space visualization. For our visualization, we drop particles inside each room, and then we assign a weight to them regarding their relative location to sensors. Avis et al. present the main method that we use to know if a particle is affected by a sensor.

A set of visualization is offer to help user, some examples are: raw model of particles, volume rendering, 2D views and point of interest (POI) visualization. Our system allows interaction: zoom, navigation, filtering. In this paper, we will present volume rendering method used to extract content efficently.

Our tool enable user to propose new content to the RIDER model. One of the main goals of the visualization is to provide new content to update buildings models. It is a complex task to maintain building model because of human activities. Using visualization, IT architect and user can propose their building information and more over propose some improvement of the model with their knowledge. This paper details the mechanism to update model content.

Several pilots have been identified for RIDER deployment, but at the moment, only two datasets are available. These datasets contain building sensors parameters values, building global topology. We present two experimentations of our visualization software with these real datasets. The first dataset comes from a data center and the second one from a part of a building. We use our tool to extract information from data and find relevant clues to optimize building energy consumption. On the data center dataset are able to extract server case location (using temporal data to identify issue with server blade, some of them are not located at the most efficient location). The second dataset is composed by data from a set of offices, we use our software to analyze data and find patterns of missing information. Visualization allows to analyze user activity and room occupation.

Keywords: Data visualization, Analysis techniques, Volume.

\section{REFERENCES}

[1] Kapferer, W. and Riser, T., "Visualization needs and techniques for astrophysical simulations," New Journal of Physics 10(12), 125008 (15pp) (2008).

[2] Avis, D. and Bhattacharya, B. K., "Algorithms for computing D-dimensional voronoï diagrams and their duals," Advances in Computing Research 1, 159-180 (1983). 